19 Cavard, D. and Lazdunski, C. (1981) FEMS Microbiol. Lett. $12,311-316$

20 Ward, R. J., Hufton, S. E., Bunce, N. A. C., Fletcher, A. J. P. and Glass, R. E. (1992) in Plasmid Encoded Toxins (lames, R. P. F. and Lazdunski, C., eds), pp. 27I-296, Springer Verlag, Heidelberg

21 Locher, K. P., Rees, B., Koebnik, R. Mitschler, A., Moulinier, L., Rosenbusch, J. P. and Moras, D. (1998) Cell 95, $771-778$

22 Ferguson, A. D., Hofmann, E., Coulton, J. W., Diederichs, K and Welte, W. (1998) Science 282, 2215-2220

23 Buchanan, S. K., Smith, B. S., Venkatramani, L., Xia, D., Esser, L., Palnitkar, M., Chakraborty, R., van der Helm, D. and Deisenhofer, J. (1999) Nat. Struct. Biol. 6, 56-63

24 Bainbridge, G., Armstrong, G. A., Dover, L. G., Whelan, K. F. and Lakey, J. H. (1998) FEBS Lett. 432, 1 17-122

25 Davies, J. K. and Reeves, P. (1975) J. Bacteriol. 123, 96-101

26 Davies, J. K. and Reeves, P. (1975) J. Bacteriol. 123, 102-117

27 Bouveret, E., Rigal, A., Lazdunski, $\mathrm{C}$. and Benedetti, $\mathrm{H}$. (1998) Mol. Microbiol. 27, 143-157

28 Raggett, E. M., Bainbridge, G., Evans, L. J. E., Cooper, A. and Lakey, J. H. (1998) Mol. Microbiol. 28, I335-1 344
29 Gokce, l., Raggett, E. M., Hong, Q., Virden, R., Cooper, A. and Lakey, J. H. (2000) J. Mol. Biol. 30, 62I-632

29a Fourel, D., Hikita, C., Bolla, J. M., Mizushima, S. and Pages, J. M. (1990) J. Bacteriol. 172, 3675-3680

30 Evans, L. J. A., Cooper, A. and Lakey, J. H. (1996) J. Mol. Biol. 255, 559-563

31 Evans, L. J. A., Labeit, S., Cooper, A., Bond, L. H. and Lakey, J. H. (1996) Biochemistry 35, 15143-15/48

32 Garavito, R. M. and Rosenbusch, J. P. (1986) Methods Enzymol. 125, 309-315

33 Dover, L. G., Evans, L. J. A., Fridd, S. L., Bainbridge, G., Raggett, E. M. and Lakey, J. H. (2000) Biochemistry 39, 8632-8637

34 Stora, T., Lakey, J. H. and Vogel, H. (1999) Angew. Chem. int. Ed. 38, 389-392

35 Terrettaz, S., Stora, T., Duschl, C. and Vogel, H. (1993) Langmuir 9, 1361-1369

36 Lang, H., Duschl, C. and Vogel, H. (1994) Langmuir 10, 197-210

37 Bainbridge, G., Mobasheri, H., Armstrong, G. A., Lea, E. J. A. and Lakey, J. H. (1998) J. Mol. Biol. 275, 171-176

\title{
Application of electron spin resonance for investigating peptide-lipid interactions, and correlation with thermodynamics D. Marsh'
}

Max-Planck-Institut für biophysikalische Chemie, Abt. Spektroskopie, 37070 Göttingen, Germany

\begin{abstract}
Peptide-lipid interactions can be investigated with spin-labelled lipid probes by using electron spin resonance (ESR) methods that have been developed for studying lipid-protein interactions with both integral and peripheral membrane proteins and also with surface-binding proteins that additionally penetrate the membrane. This approach has the advantage that a direct comparison can be made with the databank of ESR results from the various types of membrane protein. The appropriateness of the peptides as models for membrane proteins, or for their specific segments, can then be assessed. Further, differences in behaviour can be readily identified, as for example in the case of surface-active cytolytic or fusogenic peptides. Comparison with thermodynamic predictions for membrane insertion provides a useful adjunct to the spin-label method.
\end{abstract}

Key words: apocytochrome $c$, hydropathy, myelin basic protein, $\mathrm{Na}^{+} / \mathrm{K}^{+}$-ATPase, presequence, spin label, transfer free energy. Abbreviations used: ESR, electron spin resonance; SERCA ।, sarcoplasmic/endoplasmic-reticulum $\mathrm{Ca}^{2+}$-ATPase; TM, transmembrane.

'e-mail dmarsh@gwdg.de

\section{Introduction}

Electron spin resonance (ESR) spectroscopy of spin-labelled lipid chains has proved to be a valuable method for studying rotational molecular dynamics in biological membranes $[1,2]$. This is because the rate of rotational motion required for averaging the angular spectral anisotropy almost exactly matches that of the lipid-chain motions in fluid membranes. Consequently, spin-label ESR has found wide application in studying lipidprotein interactions with integral, peripheral and membrane-penetrant proteins [3-5]. The same approaches may also be applied to investigate peptide-lipid interactions [6-8].

The following analogies with membrane proteins are found (see $[5,9,10]$ ). (1) Transmembrane peptides in their oligomeric state result in a population of lipids whose chain rotational motion is directly restricted at the hydrophobic peptidelipid interface [11-13]. This population is resolved in the ESR spectrum of lipids spin-labelled close to the terminal methyl end of the chains as a second component distinct from the fluid bilayer lipids. Quantification of this second component by difference spectroscopy yields both the stoichiometry and selectivity (for different spin-labelled 
Table I

Free energy of transfer from water, $\Delta G_{\text {transf }}$ and hydrophobic moment, $\mu_{H}^{\alpha}$, of various peptides calculated according to the membrane-interface and octanol scales of White and Wimley [22]

$\mathrm{N}$ - and $\mathrm{C}$-termini without end groups are assumed to be uncharged. For $\mathrm{M} / 3$ core, no end groups are included. For transmembrane peptides, transfer free energies are particularly favourable on the interfacial scale because the interfacial anchoring residues at $\mathrm{N}$ - and $\mathrm{C}$ termini are included. $N$, number of residues; Ac, acetyl; Fm, formyl; Etn, ethanolamine. pCOIV, presequence of bovine cytochrome oxidase subunit IV: POMpA, signal peptide of Escherichia coli outer membrane protein OmpA (including the first four residues of the mature protein); $\mathrm{K} 27$, apolar domain of the minK (ISK) $\mathrm{K}^{+}$-channel-associated protein; $M / 3$ core, apolar domain of the $M / 3$ bacteriophage coat protein: WALPn, Fm-AW $2(\mathrm{LA})_{n-6} \mathrm{~W}_{2} \mathrm{~A}-\mathrm{Etn}$ peptide; $\mathrm{KALPn}, \mathrm{Ac}_{-}-\mathrm{GK}_{2}(\mathrm{LA})_{n-6} \mathrm{~K}_{2} \mathrm{~A}-\mathrm{NH}_{2}$ peptide.

\begin{tabular}{|c|c|c|c|c|c|c|c|}
\hline \multirow[b]{2}{*}{ Peptide } & \multirow[b]{2}{*}{ Sequence } & \multirow[b]{2}{*}{$N$} & \multicolumn{2}{|c|}{$\Delta G_{\text {transf }}(\mathrm{kcal} / \mathrm{mol})$} & \multicolumn{2}{|l|}{$\mu_{H}^{\alpha}$} & \multirow[b]{2}{*}{ Reference* } \\
\hline & & & Interface & Octanol & Interface & Octanol & \\
\hline \multicolumn{8}{|l|}{ Cytolytic } \\
\hline Melittin & $\begin{array}{l}\text { Fm-GIGAVLKVLTTGLPALISWIKRKRQQ- } \\
\mathrm{NH}_{2}\end{array}$ & 26 & -0.4 & +8.4 & 5.2 & 11.5 & {$[2 \mid]$} \\
\hline \multicolumn{8}{|l|}{ Presequence } \\
\hline pCOIV & MLSLRQSIRFFKPATRTLCSSRYLL-NH & 25 & -3.0 & +2.6 & 3.7 & 8.1 & {$[20]$} \\
\hline pOmpA & MKKTAIAIAVALAGFATVAQAAPKD & 25 & +1.3 & +12.1 & 4.1 & 10.4 & [23] \\
\hline \multicolumn{8}{|l|}{ Surface } \\
\hline $\mathrm{Lys}_{4}$ & KKKK & 4 & +0.6 & +11.0 & 0.4 & 1.3 & {$[16]$} \\
\hline $\mathrm{Lys}_{5}$ & KKKKK & 5 & +1.6 & +13.8 & 1.2 & 3.4 & {$[16]$} \\
\hline \multicolumn{8}{|l|}{$\begin{array}{l}\text { Trans- } \\
\text { membrane }\end{array}$} \\
\hline $\mathrm{K} 27$ & KLEALYILMVLGFFGFFTLGIMLSYIR & 27 & -10.1 & -8.2 & 1.6 & 1.6 & {$[24,25]$} \\
\hline $\mathrm{K} 27(\Delta \mathrm{L} 2)$ & KEALYILMVLGFFGFFTLGIMLSYIR & 26 & -9.6 & -7.0 & 1.0 & 3.8 & [13] \\
\hline MI3 core & -YIGYAWAMWWIVGATIGI- & 19 & -4.2 & -5.3 & 0.9 & 5.6 & {$[12,26]$} \\
\hline Gramicidin A & Fm-VGALAWWLWLWLW-Etn & 15 & -11.5 & -12.4 & - & - & [27] \\
\hline WALPI6 & Fm-AWWLALALALALAWWA-Etn & 16 & -11.5 & -10.5 & 2.5 & 3.4 & [27] \\
\hline WALPI7 & Fm-AWWLALALALALALWWA-Etn & 17 & -12.0 & -11.7 & 1.0 & 0.2 & {$[27]$} \\
\hline WALPI9 & Fm-AWWLALALALALALALWWA-Etn & 19 & -12.4 & -12.5 & 4.4 & 5.7 & [27] \\
\hline WALP23 & $\begin{array}{l}\text { Ac-GWWLALALALALALALALALWWA- } \\
\text { Etn }\end{array}$ & 23 & -13.4 & -13.3 & 3.4 & 5.5 & [28] \\
\hline KALP23 & Ac-GKKLALALALALALALALALKKA-NH ${ }_{2}$ & 23 & -2.0 & +6.3 & 1.3 & 2.6 & {$[28]$} \\
\hline *References to ESR & studies. & & & & & & \\
\hline
\end{tabular}

lipid species) of the first shell of lipids interacting directly with the peptide assembly. These are related directly to the structure and oligomerization state in the membrane $[14,15]$. (2) Watersoluble basic peptides cause a generalized increase in packing density of the lipid chains, on binding to the surface of membranes containing anionic lipids [16-18]. This is best detected from the decreased mobility of lipids spin-labelled at the polar headgroup end of the chains, but extends throughout the entire chain. The extent of ESR spectral perturbation is a measure of the strength of the interaction and also of the selectivity between spin-labelled lipid species with different polar headgroups. (3) Surface-bound peptides that partially penetrate the membrane induce ESR spectral changes that are a combination of those described under (1) and (2) $[19,20]$. They differ from transmembrane peptides in that both the lipid stoichiometry and extent of chain motional restriction is less. (4) Cytolytic peptides induce a generalized increase in lipid chain mobility at high concentrations that characterizes the formation of peptide-lipid mixed micelles [21].

Systems that have been studied by spin-label ESR include transmembrane peptides, basic peptides, presequences and cytolytic peptides (see Table 1), as well as peptide fragments from both peripheral and integral membrane proteins. Here we concentrate on the latter. One purpose of this 
overview is to compare the results obtained from spin-label ESR measurements with thermodynamic predictions based on recent determinations of transfer free energies, $\Delta G_{\text {transp }}$, to the interfacial or hydrophobic regions of the membrane [22]. It is seen from Table 1 that these hydrophobicity scales can distinguish between different modes of membrane integration. In the absence of a favourable predicted transfer free energy, membrane association must be of the classical electrostatic type. The predictive power should prove particularly useful in the case of membrane-protein fragments.

\section{Transmembrane peptides from $\mathrm{Na}^{+} / \mathrm{K}^{+}$-ATPase}

$\mathrm{Na}^{+} / \mathrm{K}^{+}$-ATPase is a relatively large integral protein, an $\alpha \beta$-heterodimer, that constitutes the sodium pump of cell plasma membranes. It transports sodium and potassium ions against their concentration gradients in an electrogenic, antiport fashion. Extensive proteolysis of the membrane-bound protein by trypsin in the presence of $\mathrm{Rb}^{+}$leaves four membrane-bound peptides from the $\alpha$-subunit in an assembly that is still able to occlude radioactive $\mathrm{Rb}^{+}$[11]. The small $\beta$-subunit is left intact on trypsinolysis. From $\mathbf{N}$-terminal sequencing, molecular masses and candidate cleavage sites, the membrane-bound tryptic peptides correspond to sequence positions 68-165, $263-347,737-826$ and $834-1016$ of the $\alpha$-subunit (numbering for sheep kidney pump).

$\mathrm{Rb}^{+}$occlusion, which is lost on more extensive trypsinization of the 834-1016 fragment in the absence of $\mathrm{Rb}^{+}$, is the only functional property that can be assayed for the transmembrane segments. Other information on whether the trypsinized preparation retains the transmembrane assembly characteristic of the native protein can be obtained by studying the lipid-protein interactions and rotational diffusion of the protein by spin-label ESR. It is found that both the number of lipids ( $\approx 32$ per protomer) surrounding the intramembranous perimeter and the major features of the lipid-headgroup selectivity of interaction are preserved in the trypsinized membranes $[11,29]$. Additionally, the overall rotational diffusion rate of the spin-labelled intramembranous peptide assembly that was determined by saturation-transfer ESR is unchanged on trypsinization [11]. Because the latter is determined by the intramembranous cross-section of the protein [2], this provides further evidence that the structural integrity of the intramembranous assembly is preserved after extensive trypsinization.

Hydropathy profiles can be used to predict which transmembrane segments are contained within the various tryptic peptides. The thermodynamic whole-residue hydrophobicity scale obtained by White and Wimley [22] for partitioning of Ac-WLXLL peptides into octanol is found to have good predictive properties for the sarcoplasmic/endoplasmic-reticulum $\mathrm{Ca}^{2+}$-ATPase (SERCA 1) (D. Marsh, unpublished work). The positions of the 10 ( $\alpha$-helical) transmembrane segments of the latter, unlike those for the $\mathrm{Na}^{+} / \mathrm{K}^{+}$-ATPase, are now known from the crystal structure [31]. Applying a similar hydropathy analysis for the $\mathrm{Na}^{+} / \mathrm{K}^{+}$-ATPase predicts the following transmembrane (TM) segments for the $\alpha 1$ subunit from sheep kidney, based on analogy with the 10-helix motif of the $\mathrm{Ca}^{2+}$-ATPase: TM1, 89-107; TM2, 123-141; TM3 and TM4, 284-322; TM5 and TM6, 768-787; TM7, 849878; TM8, 906-924; TM9, 946-964 and TM10, 967-994. Hence the three smaller tryptic peptides are predicted to contain two transmembrane segments each, corresponding to the putative pairs : TM1-TM2, TM3-TM4 and TM5-TM6. The larger C-terminal tryptic peptide is predicted to contain four putative transmembrane segments: TM7-TM10. It is the latter that is necessary for retention of $\mathbf{R b}$-occlusion capacity, but includes only one residue that contributes to a $\mathrm{Ca}^{2+}$-binding site in $\mathrm{Ca}^{2+}$-ATPase.

Although the overall pattern is similar, there are significant differences in the hydropathy profiles between $\mathrm{Ca}^{2+}$-ATPase and $\mathrm{Na}^{+} / \mathrm{K}^{+}$-ATPase (see Figure 1). These possibly correlate with differing biophysical/structural properties of the two proteins. The number of motionally restricted (i.e. first-shell) lipids per protomer is considerably larger for the $\mathrm{Na}^{+} / \mathrm{K}^{+}$-A'TPase than for the $\mathrm{Ca}^{2+}$ ATPase [15]. This difference is greater than would be expected merely due to the presence in the former of the $\beta$-subunit, which is predicted to have only one transmembrane span. It is unlikely that the difference can be attributed to different states of oligomerization in the membrane. $\mathrm{Ca}^{2+}$-ATPase is monomeric in the crystal, a state which exposes the maximum intramembranous perimeter (per monomer) to the lipid. In addition, trypsinized $\mathrm{Na}^{+} / \mathrm{K}^{+}$-ATPase preparations have a considerable content of $\beta$-structure [32], whereas extensively proteolysed $\mathrm{Ca}^{2+}$-ATPase is mostly $\alpha$-helical [33]. Although it cannot be excluded that $\beta$-structure in trypsinized $\mathrm{Na}^{+} / \mathrm{K}^{+}-\mathrm{ATPase}$ is confined to extra- 
membranous regions, the nicotinic acetylcholine receptor provides a possible precedent for mixed $\alpha / \beta$ structure within the membrane [34].

The major differences from the hydropathy profiles of the $\mathrm{Ca}^{2+}$-ATPase are the following (see Figure 1). The hydrophobicity of TM9 is low and those of TM8 and TM10 are relatively high for $\mathrm{Na}^{+} / \mathrm{K}^{+}-\mathrm{ATPase}$, and vice-versa for $\mathrm{Ca}^{2+}-\mathrm{ATP}$ ase. This could be a result of switching the function of TM8 and TM9 in the two P2-type ATPases (see [35]). Neither TM3 and TM4, nor TM5 and TM6, are resolved as two peaks in the hydropathy profiles of $\mathrm{Na}^{+} / \mathrm{K}^{+}$-ATPase. The width of these peaks is also narrower than for the corresponding segments in the $\mathrm{Ca}^{2+}$-ATPase. Finally, the width of the hydropathy peak for TM7 is considerably larger than that for $\mathrm{Ca}^{2+}$. ATPase. Whether these differences can be attributed to transmembrane $\beta$-structure and the rather unlikely possibility of a radically different intra- membranous structure is not yet known. What is clear, however, is that the hydropathy profile of the $\mathrm{Na}^{+} / \mathrm{K}^{+}$-ATPase does not fit the 10-helix paradigm as well as does that of SERCA 1.

\section{Peptides from apocytochrome $c$}

Apocytochrome $c$, the basic haem-free precursor of cytochrome $c$, binds strongly to anionic lipid membranes. Correspondingly, the spectral anisotropy of spin-labelled lipids (measured by $A_{\max }$ ) is increased at all positions of chain labelling, while still preserving the chain mobility gradient characteristic of fluid lipid bilayers [36]. Additionally, however, a second component characteristic of a more motionally restricted lipid population appears in the ESR spectra of lipids spin-labelled towards the terminal methyl end of the chains. In analogy with the results from transmembrane peptide segments, the motionally restricted lipid population is attributed to penetration of part of

\section{Figure 1}

Hydropathy profile for $\mathrm{Na}^{+} / \mathrm{K}^{+}$-ATPase $\alpha$ l subunit from sheep kidney (solid line) and SERCA I Ca ${ }^{2+}$-ATPase from rabbit (dashed line) calculated with the octanol whole-residue hydrophobicity scale of White and Wimley [22]

A sliding window of 19 residues is used for the averaging. Horizontal bars are the known transmembrane segments of SERCA I [31] and the predictions from hydropathy for the $\mathrm{Na}^{+} / \mathrm{K}^{+}$-ATPase. The residue numbering for $\mathrm{Ca}^{2+}$-ATPase is increased by 20 for better alignment. Tryptic cleavage points for the transmembrane domains of $\mathrm{Na}^{+} / \mathrm{K}^{+}$-ATPase are indicated by dotted vertical lines. Note: $\mid \mathrm{kcal}=4.184 \mathrm{~kJ}$.

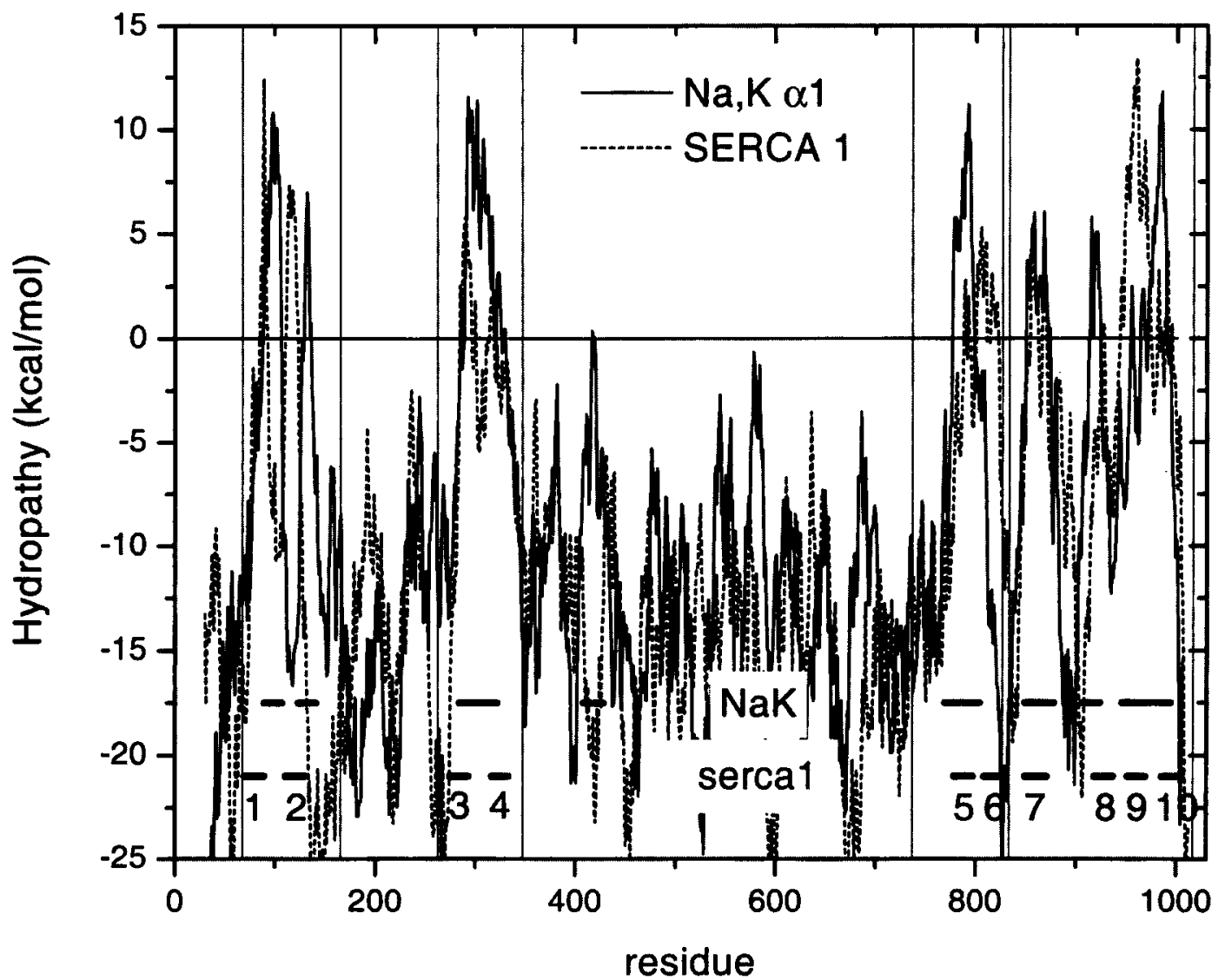


Table 2

Free energy of transfer, $\Delta G_{\text {transi }}$ from water to the membrane interface, or to octanol, calculated according to the scales of White and Wimley [22], for peptides derived from horse heart apocytochrome $c$

Peptides containing residue I have an acetylated $\mathrm{N}$-terminus. Othenwise, $\mathrm{N}$ - and $\mathrm{C}$-termini are assumed to be uncharged. $\Delta \mathrm{A}_{\text {max }}$ is the increase in outer hyperfine splitting of phosphatidylglycerol spin-labelled on the $5 \mathrm{C}$ atom of the sn- 2 chain, and $n_{\mathrm{b}}$ is the number of lipids per peptide that corresponds to the population of motionally restricted phosphatidylglycerol spin-labelled on the $12 \mathrm{C}$ atom, when the

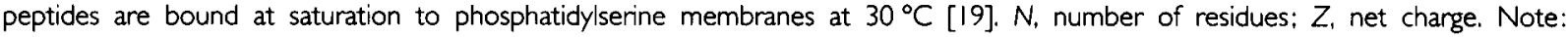
I $\mathrm{kCal}=4.184 \mathrm{~kJ}$

\begin{tabular}{|c|c|c|c|c|c|c|}
\hline \multirow{2}{*}{$\begin{array}{l}\text { Sequence } \\
\text { positions }\end{array}$} & \multirow[b]{2}{*}{$N$} & \multirow[b]{2}{*}{$Z$} & \multicolumn{2}{|c|}{$\Delta G_{\text {transf }}(\mathrm{kcal} / \mathrm{mol})$} & \multirow[b]{2}{*}{$\Delta A_{\max }$ (Gauss) } & \multirow[b]{2}{*}{$n_{b}(\mathrm{~mol} / \mathrm{mol})$} \\
\hline & & & Interface & Octanol & & \\
\hline $1-38$ & 38 & +5 & +8.8 & +35.2 & +2.9 & 1.4 \\
\hline $1-59$ & 59 & +7 & +11.5 & +49.7 & +2.25 & 4.4 \\
\hline $1-65$ & 65 & +6 & +15.9 & +58.1 & +2.5 & 4.9 \\
\hline $66-80$ & 15 & +1 & +2.2 & +13.5 & 0.0 & 0 \\
\hline $39-104$ & 66 & +4 & +19.5 & +62.4 & +2.9 & 2.9 \\
\hline $60-104$ & 45 & +2 & +16.7 & +48.0 & Small* & \\
\hline $81-104$ & 24 & +2 & +6.8 & +25.8 & +3.15 & 1.7 \\
\hline $1-104 t$ & 104 & +9 & +31.6 & +97.9 & +3.75 & 4.3 \\
\hline $\begin{array}{l}\text { *Weak bind } \\
\text { tFull-length }\end{array}$ & $\begin{array}{l}\text { than s } \\
\text { chrom }\end{array}$ & & & & & \\
\hline
\end{tabular}

the precursor protein into the hydrophobic interior of the membrane. Penetration of the protein into the lipid membrane is thought to be of direct relevance to the import of apocytochrome $c$ into the mitochondrion. Unlike most other imported mitochondrial proteins, the cytochrome $c$ precursor does not bear a presequence and its import is not dependent on ATP or the membrane potential, nor has any specific receptor protein for apocytochrome $c$ been identified.

The interaction with negatively charged lipid membranes of peptide fragments derived from apocytochrome $c$ has been studied by spin-label ESR spectroscopy in an attempt to identify those sections of the protein responsible for membrane penetration [19]. The peptides used for this study are given in Table 2 . With the exceptions of fragment 66-80, which does not bind at all, and fragment 60-104, which binds only weakly, all other peptides studied increase the spectral anisotropy of a $5 \mathrm{C}$ atom position spin label and induce a motionally restricted lipid population assayed with a $12 \mathrm{C}$ atom position spin label. Whereas all strongly binding peptides induce similar increases in spectral anisotropy of the $5 \mathrm{C}$ atom position label on surface binding, the size of the lipid population that is motionally restricted by membrane-penetrant parts of the peptide differs considerably. In particular, it is interesting that the values of $n_{b}$ for the complementary fragments 1-38 and 39-104 add up to that for the full-length protein. Such complementarity is not seen, however, with the other, multiple fragments. This suggests that these fragments may be cleaved at boundaries within penetrant regions and/or secondary structural elements of the entire protein.

The free energies predicted for transfer of the peptides both to the membrane interface and to the hydrophobic core (i.e. to octanol) are all positive (see Table 2). Binding of apocytochrome $c$ and its peptide fragments to negatively charged lipid membranes is therefore entirely electrostatic in origin. This is consistent with the ionic strength dependence of binding $[19,36]$ and the fact that peptide fragment $60-80$ with a single net positive charge (see Table 2) does not bind. Also, the relatively large peptide fragment $60-104$ with net charge of only +2 binds weakly. It should be noted, however, that membrane affinities given in Table 2 are lower estimates. They correspond to the membrane-associated peptide in a random coil conformation. Both apocytochrome $c$ and several of its constituent peptides assume considerable $\alpha$-helical structure on membrane binding [19]. Experiments with melittin indicate that $\alpha$-helix formation contributes an additional $-1.7 \mathrm{~kJ}$ $(-0.4 \mathrm{kcal}) / \mathrm{mol}$ to the transfer free energy for each residue in the helix [37]. A comparable value of $-2.5 \mathrm{~kJ}(-0.6 \mathrm{kcal}) / \mathrm{mol}$ per residue has been 
obtained for a peptide that forms $\beta$-sheets on membrane association [38].

In view of the above, membrane-penetrant sections of the peptides must therefore be rather localized. This is evident also from the relatively low lipid stoichiometries, $n_{\mathrm{b}}$ (see Table 2), and the fact that the degree of chain motional restriction is considerably less than that for integral transmembrane peptides. Putative localized membrane-penetrant regions can be identified from hydropathy profiles evaluated with different sizes of the sliding window over which residues are averaged. Such segments are encountered first with window sizes that are greater for the inter- facial scale than for the octanol scale. 'Hotspots' of hydrophobic penetration that are energetically favourable relative to an interfacial location are detected first for a window of seven residues. Figure 2 gives the hydropathy profiles for apocytochrome $c$ evaluated using both the interfacial and octanol scales of White and Wimley [22], and a window of five residues. Three 5-7-residue segments are predicted preferentially to penetrate the hydrophobic core of the membrane. These correspond to residue positions 30-36, 80-85 and 94-98, which have favourable transfer free energies relative to the interface of $\Delta \Delta G_{\text {transs }}$ of $-3.3,-5.0$ and $-6.7 \mathrm{~kJ} / \mathrm{mol}(-0.8,-1.2$ and

Figure 2

Hydropathy profile for horse heart apocytochrome c, calculated with the interfacial (dashed line) and octanol (solid line) hydrophobicity scales of White and Wimley [22]

\begin{abstract}
The transfer free energy from the membrane to water is averaged over a sliding window of five residues. Dashed and solid horizontal lines represent regions predicted to be energetically favourable in the membrane interface (IF) and hydrophobic core (oct), respectively. Only at three positions is transfer to octanol favoured over that to the interface. Dotted vertical lines indicate cleavage points in the various peptide fragments. Note: । $\mathrm{kcal}=4.184 \mathrm{~kJ}$.
\end{abstract}

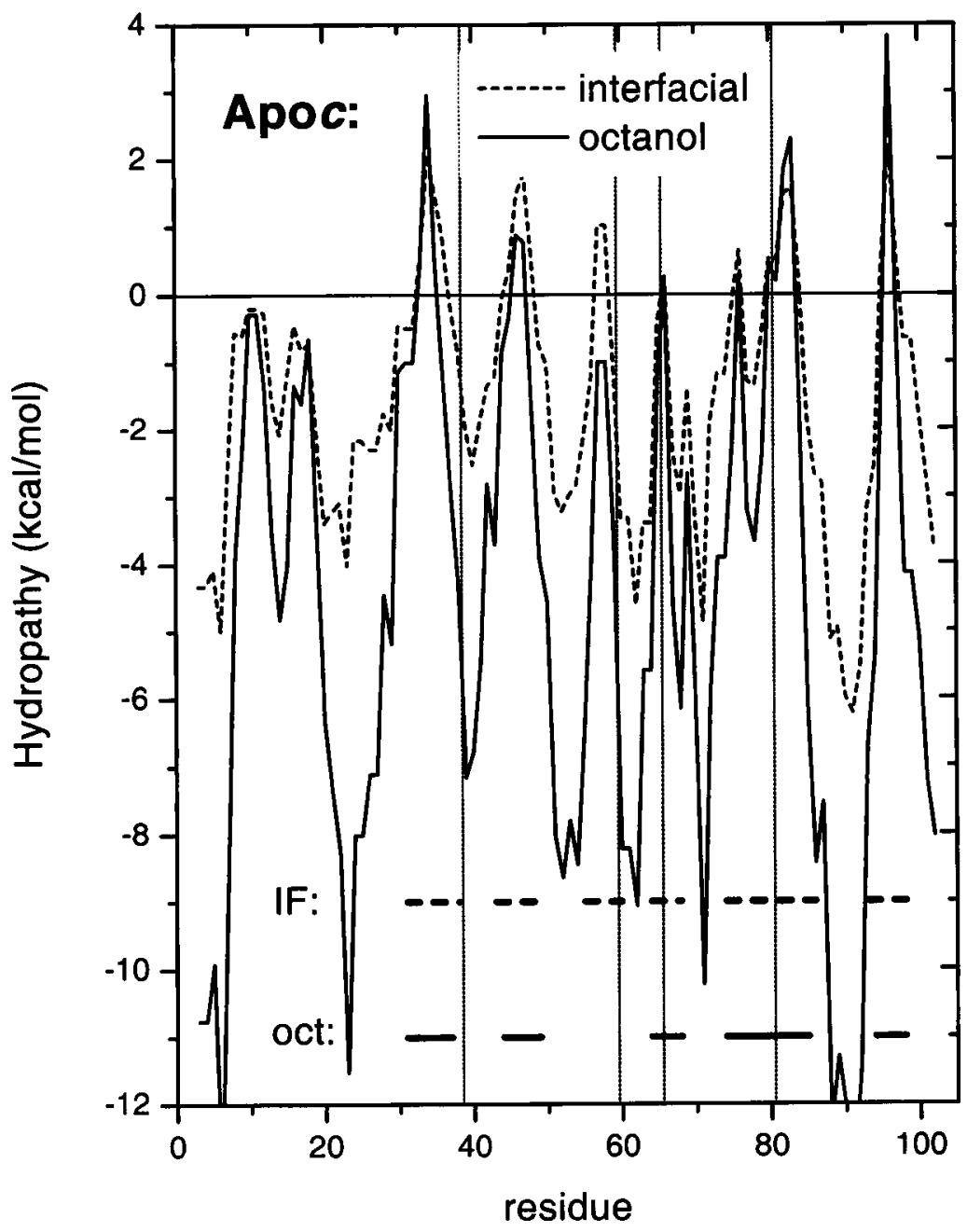


$-1.6 \mathrm{kcal} / \mathrm{mol}$ ) respectively. The first and longest is confined to peptide $1-38$ and the remainder to the complementary fragment 39-104. None lie within the $66-80$ peptide. Two segments with a possible potentiating effect (because they have a favourable location at the membrane interface) lie within the longer 1-59 and 1-65 peptides containing the $\mathrm{N}$-terminus. At the $\mathrm{C}$-terminus, one hydrophobic segment abuts the first residue of the 81-104 peptide. This may perturb the lipid interactions with this peptide fragment, relative to those with the full-length protein.

On the whole, the spin-label ESR results on the peptides agree reasonably well with the thermodynamic predictions. Comparison with ESR results from the full-length protein is hampered, however, by the fact that some of the peptides have different packing densities at saturation binding from that of the whole protein [19]. In addition, direct experimental evidence indicates that the $\mathrm{N}$-terminal section of the full-length protein, spin-labelled at Cys-14 or Cys-17, also penetrates the membrane $[39,40]$. A five-residue section of the protein $(16-20)$ is predicted to have a transfer free energy to the hydrophobic core that is marginally favourable relative to the interface $\left[\Delta \Delta G_{\text {transt }}=-0.4 \mathrm{~kJ}(-0.1 \mathrm{kcal} / \mathrm{mol})\right]$ (in this region (see Figure 2).

\section{Conclusion}

Like apocytochrome $c$, the myelin basic protein binds only to negatively charged lipid membranes but induces a motionally restricted lipid population; in this case more strongly than does apocytochrome $c[41,42]$. Complementary peptide fragments produced by cleavage at the single Trp-115 also bind, but only the larger N-terminal fragment (F1) induces a motionally restricted lipid component, and to a lesser extent than does the whole protein $[42,43]$. Myelin basic protein contains two appreciable stretches of amino acids (residues $34-44$ and 107-116) with favourable transfer free energies $\left[\Delta G_{\text {transt }}=-6.2\right.$ and $-11.7 \mathrm{~kJ} / \mathrm{mol}(-1.5$ and $-2.8 \mathrm{kcal} / \mathrm{mol}) \mathrm{respec}-$ tively] to the membrane interface. One of these is in fragment $F 1$ and the other contains the cleavage point. The only segment of appreciable size with a favourable free energy of transfer to the hydrophobic core of the membrane (i.e. to octanol), relative to the interface, is confined to the $F 1$ fragment. This segment (residues $85-93 ; \Delta G_{\text {transt }}$ $=-2.2 \mathrm{kcal} / \mathrm{mol}$ ) is longer than the hydrophobic segments in apocytochrome $c$ (see Figure 2) and is situated close to the second segment that favours an interfacial location. Possibly cleavage in the second interfacial site disrupts synergy with the hydrophobic segment and hence reduces penetration of fragment F1 into the membrane.

Finally, the amphipathic cytochrome oxidase subunit IV presequence, pCOIV, has been found to evince a motionally restricted lipid population on binding to negatively charged lipid membranes [20]. The entire peptide is predicted to have a favourable location at the interface, but not in the hydrophobic core (see Table 1). However, residues 7-11 (SIRFF) are predicted to be more favourably located in the hydrophobic core $\left[\Delta G_{\text {transf }}=-9.6 \mathrm{~kJ}(-2.3 \mathrm{kcal}) / \mathrm{mol}\right]$ than in the interface $\left[\Delta G_{\text {transf }}=-6.7 \mathrm{~kJ} \quad(-1.6 \mathrm{kcal}) / \mathrm{mol}\right]$ and this preference persists to an attenuated extent on including several further residues. The alternating distribution of polar and apolar residues that is characteristic of presequences gives rise to a sensitive dependence on lipid composition, particularly modulation by the mitochondrial lipid cardiolipin [20].

I thank all my colleagues and collaborators involved in ESR studies of protein-lipid interactions and especially Frau B. Angerstein for synthesis of spin-labelled lipids.

\section{References}

1 Marsh, D. (1981) in Membrane Spectroscopy. Molecular Biology, Biochemistry and Biophysics, vol. 31 (Grell, E., ed.), pp. 5|-142, Springer-Verlag, Berlin

2 Marsh, D. and Horváth, L. I. (1989) in Advanced EPR. Applications in Biology and Biochemistry (Hoff, A. J., ed.), pp. 707-752, Elsevier, Amsterdam

3 Marsh, D. (1989) in Biological Magnetic Resonance, vol. 8 (Berliner, L. J. and Reuben, J., eds), Pp. 255-303, Plenum Publishing, New York

4 Marsh, D. (1985) in Progress in Protein-Lipid Interactions, vol. I (Watts. A. and de Pont, J. J. H. H. M., eds), Pp. 143-172, Elsevier, Amsterdam

5 Sankaram, M. B. and Marsh, D. (1993) New Compr. Biochem., vol. 25, 127-162

6 Findlay, J. B. C. and Marsh, D. (1995) in lon Channels - a Practical Approach (Ashley, R. ed.), Pp. 24I-267, IRL Press, Oxford

7 Marsh, D. (1996) Biochem. J. 315, 345-361

8 Marsh. D. (1999) Methods Enzymol. 294, 59-92

9 Marsh, D. and Horváth, L. I. (1998) Biochim. Biophys. Acta 1376, 267-296

10 Marsh, D. (1995) in Biomembranes, vol. I (Lee, A. G., ed.), pp. 137-186, JAl Press, Greenwich, CT

II Esmann, M., Karlish, S. J. D., Sottrup-Jensen, L. and Marsh, D. (1994) Biochemistry 33, 8044-8050

12 Peelen, S. J. C.J., Sanders, J. C., Hemminga, M. A. and Marsh, D. (1992) Biochemistry 3I, 2670-2677

13 Horváth, L. I., Heimburg, T., Kovachev, P., Findlay, J. B. C., Hideg, K. and Marsh, D. (1995) Biochemistry 34, 3893-3898 
14 Marsh, D. (1993) New Compr. Biochem. 25, 41-66

15 Marsh, D. (1997) Eur. Biophys. J. 26, 203-208

16 Kleinschmidt, J. H. and Marsh, D. (1997) Biophys. J. 73, 2546-2555

17 Sankaram, M. B., De Kruijff, B. and Marsh, D. (1989) Biochim. Biophys. Acta 986, 315-320

18 Sankaram, M. B., Brophy, P. J. and Marsh, D. (1989) Biochemistry 28, 9699-9707

19 Jordi, W., De Kruijf, B. and Marsh, D. (1989) Biochemistry 28, 8998-9005

20 Snel, M. M. E., de Kroon, A. I. P.M. and Marsh, D. (1995) Biochemistry 34, 3605-36/3

21 Kleinschmidt, J. H., Mahaney, J. E., Thomas, D. D. and Marsh, D. (1997) Biophys. J. 72, 767-778

22 White, S. H. and Wimley, W. C. (1999) Annu. Rev. Biophys. Biomol. Struct. 28, 319-365

23 Sankaram, M. B., Marsh, D., Gierasch, L. M. and Thompson, T. E. (1994) Biophys. J. 66, 1959-1968

24 Aggeli, A., Boden, N., Cheng, Y.-L., Findlay, J. B. C., Knowles, P. F., Kovatchev, P., Tumbull, P. J. H., Horváth, L. I. and Marsh, D. (1996) Biochemistry 35, 16213-16221

25 Horváth, L. I., Knowles, P. F., Kovachev, P., Findlay, J. B. C. and Marsh, D. (1997) Biophys. J. 73, 2588-2594

26 Wolfs, C. J. A.M., Horváth, L. I., Marsh, D., Watts, A. and Hemminga, M. A. (1989) Biochemistry 28, 9995-10001

27 de Planque, M. R. R., Greathouse, D. V., Koeppe, II, R. E., Schäfer, H., Marsh, D. and Killian, J. A. (1998) Biochemistry 37, 9333-9345

28 de Planque, M. R. R., Kruijtzer, J. A. W., Liskamp, R. M. J. Marsh, D., Greathouse, D. V., Koeppe, II, R. E., De Kruijff, B. and Killian, J. A. (1999) J. Biol. Chem. 274, 20839-20846
29 Arora, A., Esmann, M. and Marsh, D. (1998) Biochim. Biophys. Acta 1371, 163-167

30 Reference deleted

31 Toyoshima, C., Nakasako, M., Nomura, N. and Ogawa, H. (2000) Nature (London) 405, 647-655

32 Heimburg, T., Esmann, M. and Marsh, D. (1997) J. Biol. Chem. 272, 25685--25692

33 Corbalán-García, S., Teruel, J. A., Villalain, J. and GómezFemández, J. C. (1994) Biochemistry 33, 8247-8254

34 Unwin, N. (1993) J. Mol. Biol. 229, 1101-1 124

35 Møller, J. V., Juul, B. and LeMaire, M. (1996) Biochim. Biophys. Acta |286, |-5|

36 Görrissen, H., Marsh, D., Rietveld, A. and De Kruijff, B. (1986) Biochemistry 25, 2904-2910

37 Ladokhin, A. S. and White. S. H. (1999) J. Mol. Biol. 285 1363-1369

38 Wimley, W. C., Hristova, K., Ladokhin, A. S., Silvestro, L. Axelsen, P. H. and White, S. H. (1998) J. Mol. Biol. $1091-1110$

39 Snel, M. M. E., De Kruijff, B. and Marsh, D. (1994) Biochemistry 33, 11150-11157

40 Snel, M. M. E. and Marsh, D. (1994) Biophys. J. 67 737-745

4I Sankaram, M. B., Brophy, P. J. and Marsh, D. (1989) Biochemistry 28, 9685-9691

42 Sankaram, M. B., Brophy, P. J. and Marsh, D. (1989) Biochemistry 28, 9692-9698

43 Hayer-Hartl, M., Brophy, P. J., Marsh, D. and Watts, A. (1993) Biochemistry 32, 9709-97/3

Received 20 February 2001

\section{Structural model of a voltage-gated potassium channel based on spectro- scopic data \\ P. I. Haris' \\ Department of Biological Sciences, De Montfort University, The Gateway, Leicester, LEI 9BH, U.K.}

\begin{abstract}
It is estimated that membrane proteins comprise as much as $30 \%$ of most genomes. Yet our knowledge of membrane-protein folding is still in its infancy. Consequently, there is a great need for developing approaches that can further advance our understanding of how peptides and proteins interact with membranes and thereby attain their folded structure. An approach that we have been exploring involves dissecting voltage-gated ion channels into simple peptide domains for the purpose of determining their structure in different media using physical techniques. We have synthesized peptides corresponding to the six mem-
\end{abstract}

Key words: $\boldsymbol{\alpha}$-helix, ion channel, membrane protein, spectroscopy. Abbreviations used: FTIR, Fourier-transform IR

'e-mail pharis@dmu.ac.uk brane-spanning segments, as well as the pore domain, of the Shaker channel and characterized their secondary structures. From these studies we have developed a model for the transmembrane structure of the Shaker potassium channel that is constructed from $\alpha$-helices. The hard structural data obtained from these studies lends support to the recent theoretical models of this channel protein that have been developed by others.

\section{Introduction}

Despite their importance, and the fact that they make up about $30 \%$ of most genomes, our understanding of membrane-protein structure remains rather poor. Such is the scale of our ignorance that high-resolution X-ray structures of about a dozen different membrane proteins are known, whereas such structures are available for hundreds of 